\title{
PEMANFAATAN DESAIN DIDAKTIS PADA PENYAJIAN DATA UNTUK SISWA DISKALKULIA SEKOLAH DASAR
}

\section{DIDACTIC DESIGN ON DATA PRESENTATION FOR DYSCALCULIA STUDENTS ELEMENTARY SCHOOL}

\author{
DESI ERFAN
}

SDN Duren Sawit 05 Jakarta

\section{Received: March 03, 2021 \\ Revised: March 06, 2021 \\ Accepted: March 10, 2021}

\begin{abstract}
Dyscalculia students are found in almost every school. They have average IQ or above but have difficulty learning mathematics, namely ontogenical obstacles, didactical obstacles, and epistemological obstacles. This study aims to overcome the learning difficulties of dyscalculia students with a didactic design on data presentation material. This study uses a qualitative approach through Didactical Design Research (Suryadi, 2013) which consists of: (1) didactic and pedagogical anticipation; (2) metapedadidactic analysis; and (3) restrostive analysis. Data collection techniques using written tests, interviews, observations, and documentation. Data validation was carried out by triangulation. The results showed that the didactic design in presenting the data could reduce the mathematics learning difficulties of the 5th grade dyscalculia students at SDN Duren Sawit 05 Jakarta until 63,1\% and it can be used as an alternative to overcome the difficulties of learning mathematics for dyscalculia students.
\end{abstract}

\begin{abstract}
Abstrak.
Siswa diskalkulia dijumpai hampir di setiap sekolah karena mereka memiliki intelegensi ratarata atau di atas rata-rata tetapi mengalami kesulitan belajar matematika yaitu ontogenical obstacles (kurangnya kesiapan mental), didactical obstacles (kesalahpahaman pengajaran guru), dan epistemological obstacles (kurangnya pengetahuan). Siswa diskalkulia sering memiliki nilai rendah, sehingga penting bagi guru memperhatikan kesulitan belajar mereka dalam meningkatkan hasil belajarnya. Penelitian ini memiliki tujuan untuk mengatasi kesulitan belajar siswa diskalkulia dengan desain didaktis pada materi penyajian data. Penelitian ini menggunakan pendekatan kualitatif melalui penerapan didactical design research dari Suryadi (2013) yang terdiri dari tiga tahapan yaitu: (1) antisipasi didaktis dan pedagogis (ADP), yaitu analisis situasi didaktis sebelum pembelajaran; (2) analisis metapedadidaktik (guru merancang situasi didaktis sesuai kebutuhan siswa sehingga terjadi proses belajar dalam diri siswa, menganalisis respon siswa, dan melakukan tindakan didaktis lanjutan); dan (3) analisis restrosfektif (membandingkan ADP dengan analisis metapedadidaktik). Teknik pengumpulan data penelitia ini menggunakan tes tertulis, wawancara, observasi, dan dokumentasi. Subjek penelitiannya adalah siswa diskalkulia kelas 5A SDN Duren Sawit 05 Jakarta yang diidentifikasi dari asesmen diagnostik. Validasi data dalam penelitian ini dilakukan dengan triangulasi dan analisis data dalam penelitian ini dilakukan secara kualitatif menurut Miles dan Hubarmen (Sugiyono, 2013) dengan tahapan pengumpulan data, penyajian data, dan penarikan simpulan. Hasil penelitian menunjukkan desain didaktis pada penyajian data dapat menurunkan kesulitan belajar matematika siswa diskalkulia kelas 5 rata-rata sebesar 63,1\%. Hasil penelitian ini dapat dijadikan alternatif untuk mengatasi kesulitan belajar matematika siswa diskalkulia sekaligus dapat meningkatkan hasil belajar materi penyajian data.
\end{abstract}

Keywords: didactical design research, learning difficulties, and data presentation

Kata kunci: $\quad$ didactical design research, kesulitan belajar, dan penyajian data

(*) Corresponding Author: desierfan2017@gmail.com

How to Cite: Erfan, D. (2021). Pemanfaatan Desain Didaktis Pada Penyajian Data Untuk Siswa Diskalkulia Sekolah Dasar. Jurnal Lingkar Mutu Pendidikan, 18 (1), 13-28. https://doi.org/10.54124/jlmp.v18i1.14

\section{PENDAHULUAN}

Menjadi salah satu guru dalah mengatasi kesulitan. Bila prestasi yang diharapkan tidak sama dengan capaian hasil belajar adalah indikasi muculnya kesulitan belajar (Rohimah 2017, 133). Kesulitan persepsi masih dialami demikian juga dengan kesulitan konseptualisasi, berbahasa, memori, pemusatan perhatian, dan penguasaan diri pada diri siswa dengan kemampuan rata-rata atau di atas 
rata-rata adalah daerah kesulitan belajar. Kesulitan belajar dikenal dengan istilah learning obstacle. Learning obstacle terbagi menjadi 3 jenis, yaitu: (1) ontogenical learning obstacle yaitu kesulitan belajar yang dialami siswa karena kurangnya kesiapan belajar. Banyak siswa kurang siap belajar karena faktor usia yang belum cukup, sehingga cara berpikir siswa yang belum cukup usia akan mempengaruhi proses dan hasil belajar mereka. Kurangnya kesiapan belajar dapat membuat fobia matematika pada siswa. Mereka takut dimarahi saat mendapat nilai rendah, takut diejek atau ditertawai saat salah menjawab soal; (2) didactical learning obstacle yaitu kesulitan belajar yang dialami siswa karena kekeliruan penyajian materi pembelajaran, bisa dari guru atau dari bahan ajar yang digunakan siswa sehingga menimbulkan kesalahpahaman konsep pada siswa; dan (3) epistemological learning obstacle yaitu kesulitan belajar yang dialami siswa karena pemahaman sebuah konsep yang tidak lengkap, dari siswa kurang membaca, tidak mau bertanya, atau jarang berlatih soal (Warfield 2014).

Kesulitan belajar siswa yang berhubungan dengan akademik sering ditemui guru terutama kesulitan belajar matematika. Matematika merupakan mata pelajaran wajib yang masih dipandang sulit bagi sebagian besar siswa sekolah dasar. Fakta yang ditemukan di kelas 5 SDN Duren Sawit 05 Jakarta yaitu masih banyaknya siswa yang memiliki kesulitan belajar materi penyajian data yang telah dipelajari di kelas 4 . Hasil asesmen diagnostik dengan 2 soal uraian membuat diagram garis dan diagram batang kepada 30 siswa kelas 5, diperoleh rata-rata nilai sebesar 67, masih dibawah nilai kriteria ketuntasan minimal (KKM) yaitu 68. Dari 30 siswa, sebagian besar siswa mempunyai kesulitan belajar penyajian diagram garis dan diagram batang dan disajikan pada Tabel 1.

Tabel 1. Kesulitan belajar penyajian data 30 siswa kelas 5 SDN Duren Sawit 05 Tahun 2020/ 2021

\begin{tabular}{lllll}
\hline No & Kesulitan Belajar Penyajian Data & Baik & Belum & $\%$ \\
\hline 1 & Menulis angka kurang rapi & 20 & 10 & 33 \\
2 & Membuat diagram tidak lurus & 10 & 20 & 66 \\
3 & Belum tepat menggunakan penggaris & 10 & 20 & 66 \\
4 & Menulis kurang rapi & 10 & 20 & 66 \\
5 & Mengurutkan bilangan masih sulit & 27 & 3 & 10 \\
6 & Lupa memberi keterangan sumbu x dan sumbu y & 13 & 17 & 56 \\
7 & Terbalik memberi keterangan sumbu x dan sumbu y & 21 & 9 & 30 \\
8 & Lupa memberi judul diagram & 10 & 20 & 66 \\
\hline
\end{tabular}

Berdasarkan Tabel 1 hampir 50\% siswa kelas 5 memiliki kesulitan belajar tentang penyajian diagram garis dan diagram batang. Hal ini mungkin disebabkan oleh tiga jenis kesulitan belajar terjadi pada siswa-siswa tersebut (Warfield 2014). Selain itu desain pembelajaran yang diterapkan guru dalam materi penyajian data juga mungkin belum memperhatikan karakteristik siswa. Oleh karena itu asesmen diagnostik perlu dilakukan guru di awal pembelajaran. Asesmen diagnostik dapat mengidentifikasi kekuatan dan kelemahan siswa, sehingga siswa-siswa berkesulitan belajar dapat diidentifikasi dan guru dapat merencanakan proses belajar mengajar yang bersinergi dengan kebutuhan siswa (Shim G.T.G. 2017).

Siswa yang mempunyai kesukaran dalam matematika disebut dengan istilah siswa diskalkulia. Siswa diskalkulia adalah siswa yang tidak mampu berhitung karena ada gangguan pada sistem syaraf pusatnya. Siswa diskalkulia memiliki kesulitan dalam perhitungan matematika dan sering mempunyai prestasi yang buruk dalam mengelola ingatan, persepsi visual, dan kemampuan visualspasial (Delgado 2019). Umumnya siswa diskalkulia lamban dan sulit berhitung, membedakan angka dan benda-benda geometri, sulit memahami soal matematika berbentuk cerita atau soal yang membutuhkan penalaran, sulit memahami konsep ruang dan waktu, sulit memahami simbol-simbol matematika, dan sulit menghapal (Wiardani 2018).

Kesulitan belajar yang dialami siswa diskalkulia menyebabkan proses dan hasil belajar siswa tidak maksimal sehingga diperlukan sebuah upaya guru agar siswa mudah memahami materi pembelajaran yang diberikannya. Upaya yang dibuat oleh guru sebelum mengajarkan ilmunya kepada siswa berdasarkan analisis yang dilakukan dikenal dengan istilah desain didaktis.

Kesulitan belajar siswa dapat diatasi salah satunya dengan cara penyusunan desain didaktis yang dilakukan oleh guru. Penyusunan desain didaktis oleh guru melalui tiga tahap yakni sebelum 
pembelajaran, saat pembelajaran, dan setelah pembelajaran. Sebelum pembelajaran, seorang guru sebaiknya mempersiapkan rencana pelaksanaan pembelajaran (RPP). Saat pembelajaran seorang guru sebaiknya memperhatikan proses pembelajarannya, apakah sudah sesuai dengan RPP yang ia buat atau belum. Setelah pembelajaran seorang guru sebaiknya menganalisis proses dan hasil belajar siswanya. Proses belajar mengajar yang dialami siswa dengan interaksi yang terjalin antara siswa, guru, dan materi ajar bisa menyebablam terjadinya kesulitan belajar (Suryadi 2013).

Terjalinnya hubungan antara guru, siswa, dan materi ajar dideskripsikan sebagai segitiga didaktis yang dapat dilihat pada Gambar1.

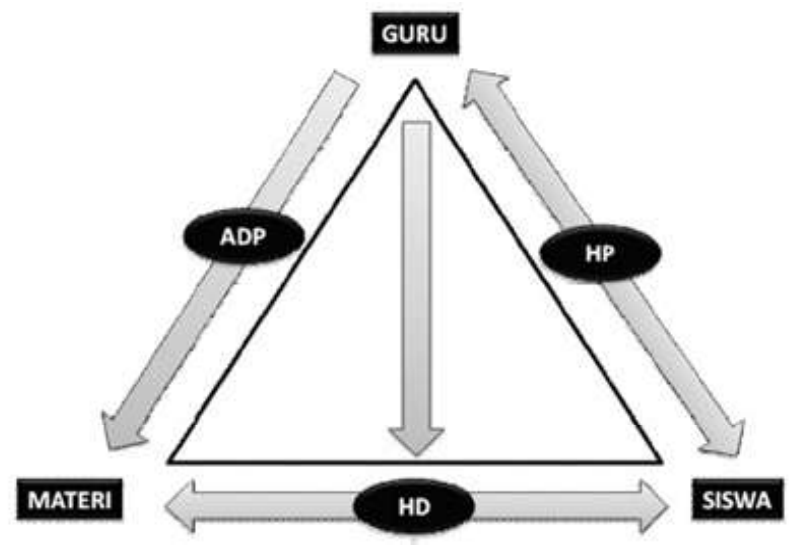

Gambar 1. Segitiga Didaktis yang dimodifikasi Kansanen (Suryadi 2013).

Segitiga didaktis pada Gambar 1 menjelaskan bahwa guru berperan untuk menciptakan situasi didaktis sehingga terjadi pembelajaran dalam diri siswa. Oleh karena itu guru harus benarbenar menguasai materi ajar, karakteristik siswa, dan membuat kondisi didaktis untuk melejitkan pembelajaran (Suryadi 2013). Seorang siswa mendapat pengetahuan dari hasil aksinya melalui formulasi dan validasi menuju pada tahap institusionalisasi. Tahap aksi, formulasi, validasi, dan institusionalisasi dinamakan Brousseau \& Warfield sebagai situasi didaktis (Warfield 2014). Keempat situasi didaktis diperjelas sebagai berikut. Situasi aksi adalah situasi dimana siswa menemukan sendiri solusi suatu permasalahan (Suryadi 2013). Situasi formulasi adalah situasi dimana siswa berdiskusi dengan siswa lainnya untuk menyelesaikan masalah. Situasi validasi adalah situasi dimana guru memperbaiki solusi siswa sehingga dihasilkan suatu kesimpulan. Situasi institusionalisasi adalah situasi dimana siswa menggunakan pengetahuan barunya untuk menyelesaikan masalah lain.

Di tingkat sekolah dasar dan menengah sudah banyak dilakukan penelitian desain didaktis melalui tahapan penelitian yang terdiri atas tiga tahapan yaitu: (1) bagaimana caranya menganalisis kondisi didaktis sebelum proses belajar mengajar (antisipasi didaktis dan pedagogis, (ADP)); (2) analisis metapedadidaktik; dan (3) analisis restrosfektif (membandingkan analisis metapedadidaktik dengan ADP). Metapedadidaktik adalah kemampuan guru untuk: (1) melihat materi, guru, dan siswa merupakan kesatuan utuh; (2) sesuai dengan keperluan kebutuhan siswa dikembangkannya situasi didaktis; (3) sebagai akibat tindakan didaktis yang dilakukan respon siswa dianalisis; dan (4) berdasarkan hasil analisis respon siswa melakukan tindakan didaktis lanjutan menuju pencapaian tujuan pembelajaran (Suryadi 2013).

Bagi siswa SD penyajian data mulai diajarkan sejak kelas 4. Penyajian data merupakan bagian dari ilmu statistik dasar dan perlu dipahami oleh siswa sekolah dasar karena siswa pasti menemukan berbagai macam data dalam kehidupan sehari-hari. Banyak kesulitan yang dialami siswa diskalkulia sekolah dasar dalam memahami materi penyajian data. Desain didaktis seorang guru diharapkan dapat mengatasi atau meminimalkan terjadinya kesulitan belajar matematika siswa diskalkulia sekolah dasar.

Hal ini sudah berhasil dilakukan, dimana hasil penelitiannya menyebutkan bahwa desain didaktis dapat menurunkan kesulitan belajar siswa kelas VII SMPIT Salman, Cirebon sebesar 82,9\%. Melihat bahwa desain didakttis dapat dilakukan di tempat lain (Abdullah 2019) maka sangat menarik untuk melihat hasil penerapan desain didaktis pada siswa diskalkulia di SDN Duren Sawit 05. Diharapkan penelitian penerapan desain didaktis ini dapat memberikan manfaat alternatif rancangan 
pembelajaran yang dapat dipakai guru untuk mengatasi atau meminimalkan terjadinya kesulitan belajar matematika siswa diskalkulia sekolah dasar.

\section{METODE PENELITIAN}

Metode yang dipakai adalah metode pendekatan kualitatif dengan memakai desain didaktis (didactical design research) (Suryadi 2013). Teknik mengumpulkan data menggunakan tes tertulis, wawancara, observasi, dan dokumentasi. Sedangkan tahapan pengumpulan data dilakukan dengan tahapan sebagai berikut: studi literatur, identifikasi siswa diskalkulia dengan asesmen diagnostik, identifikasi kesulitan belajar matematika dengan tes tertulis, analisis kesulitan belajar matematika dan materi yang akan dipelajari, membuat rancangan didaktis, implementasi rancangan didaktis, melakukan pengujian hasil implementasi rancangan didaktis, analisis hasil implementasi rancangan didaktis, dan membuat simpulan.

Dalam penelitian ini, subjek penelitian adalah siswa diskalkulia kelas 5A SDN Duren Sawit 05 Jakarta di Jalan Pendidikan 9 nomor 13 RT 008 RW 005 Jakarta Timur. Fokus penelitian ini adalah mengkaji kesulitan belajar siswa diskalkulia dalam materi penyajian data sehingga menjadi suatu dasar untuk merancang suatu desain didaktis agar dapat mengatasi atau meminimalkan kesulitan belajar matematika siswa serta meningkatkan hasil belajar penyajian data siswa diskalkulia sekolah dasar. Desain didaktis penyajian data untuk siswa diskalkulia di kelas 5 sekolah dasar dirancang dengan tahapan-tahapan yang disajikan pada Tabel 2 .

Tabel 2. Desain didaktis penyajian data untuk siswa diskalkulia kelas 5, dimodifikasi (Suryadi 2013).

\begin{tabular}{ll}
\hline Desain Didaktis & Kegiatan \\
\hline & Analisis materi penyajian data untuk siswa diskalkulia. \\
& Analisis tujuan pembelajaran untuk siswa diskalkulia. \\
& Analisis tugas untuk siswa diskalkulia. \\
Antisipasi & Guru membuat uji kesulitan belajar penyajian data \\
Didaktis dan & Siswa mengisi uji kesulitan belajar penyajian data sebelum implementasi desain didaktis. \\
Pedagogis & Guru menganalisis hasil tes uji kesulitan belajar penyajian data sebelum implementasi \\
& desain didaktis. \\
& Guru membuat RPP adaptif. \\
& Guru membuat PPT adaptif. \\
& Guru membuat instrument penilaian dengan aplikasi quiziiz, wordwall, dan kahoot. \\
\hline & Guru mengembangkan 4 situasi didaktis (aksi, formulasi, validasi, dan institusionalisasi) \\
& sesuai kebutuhan siswa diskalkulia selama proses pembelajaran virtual \\
Metapedadidaktik & Siswa mengisi uji kesulitan belajar penyajian data setelah implementasi desain didaktis \\
& Guru menganalisis hasil uji kesulitan belajar penyajian data setelah implementasi desain \\
& didaktis. \\
\hline & Guru membandingkan analisis uji kesulitan belajar siswa sebelum dan setelah \\
& implementasi desain didaktis \\
Restrosfektif & Refleksi guru dan siswa.
\end{tabular}

Validasi data dilakukan dengan triangulasi yaitu mengecek kredibilitas data dengan berbagai teknik pengumpulandata dan berbagai sumber data (Sugiyono 2013).

Analisis data dalam penelitian ini dilakukan secara kualitatif menurut Miles dan Hubarmen dengan tahapan sebagai berikut: (1) pengumpulan data; (2) penyajian data; dan (3) penarikan simpulan (Sugiyono 2013).

\section{HASIL DAN PEMBAHASAN}

Pada tahap identifikasi siswa diskalkulia dilakukan asesmen diagnostik kepada siswa kelas $5 \mathrm{~A}$. Instrumen asesmen diagnostik berupa tes tertulis materi penyajian data kelas 4 sebanyak 10 soal uraian. Siswa yang memperoleh nilai di bawah KKM yaitu di bawah 68 dikategorikan sebagai siswa diskalkulia, dan diperoleh 10 siswa diskalkulia di kelas 5A. Berikut kisi-kisi soal asesmen diagnostik untuk mengidentifikasi siswa diskalkulia di kelas 5A ditunjukkan pada Tabel 3. 
Tabel 3. Kisi-kisi asesmen diagnostik matematika diskalkulia kelas 5

\begin{tabular}{|c|c|c|c|c|c|}
\hline \multicolumn{2}{|c|}{ Kompetensi Dasar } & \multicolumn{2}{|c|}{ Indikator Soal } & \multirow{2}{*}{$\frac{\text { Bentuk Soal }}{\text { Uraian }}$} & \multirow{2}{*}{$\frac{\text { Nomor Soal }}{1}$} \\
\hline 3.11 & Menjelaskan data & 3.11.1 & Siswa dapat menjelaskan pengertian data & & \\
\hline & diri peserta didik & 3.11 .2 & Siswa mampu membedakan data dan bukan data & & 2 \\
\hline & dan lingkungannya & 3.11 .3 & Siswa dapat memberi contoh data diri siswa & & 3 \\
\hline & yang disajikan dalam & 3.11 .4 & Siswa dapat memberi contoh data lingkungannya & & 4 \\
\hline & $\begin{array}{l}\text { bentuk diagram } \\
\text { batang }\end{array}$ & 3.11 .5 & $\begin{array}{l}\text { Siswa dapat menjelaskan cara pengumpulkan data } \\
\text { secara langsung }\end{array}$ & & 5 \\
\hline & & 3.11 .6 & $\begin{array}{l}\text { Siswa dapat menjelaskan cara pengumpulkan data } \\
\text { secara tidak langsung }\end{array}$ & & 6 \\
\hline & & 3.11 .7 & Siswa dapat menjelaskan pengertian diagram & & 7 \\
\hline & & 3.11 .8 & Siswa dapat menyebutkan bentuk-bentuk diagram & & 8 \\
\hline & & 3.11 .9 & Siswa dapat menyajikan diagram batang & & 9 \\
\hline & & 3.11 .10 & Siswa dapat menafsirkan diagram batang & & 10 \\
\hline
\end{tabular}

Pada tahap identifikasi kesulitan belajar matematika sebelum implementasi desain didaktis, 10 siswa diskalkulia di kelas $5 \mathrm{~A}$ diberikan tes tertulis 10 soal uraian tentang materi penyajian data kelas 5 dengan kisi-kisi soal uji kesulitan belajar matematika ditunjukkan pada Tabel 4.

Tabel 4. Kisi-kisi uji kesulitan belajar matematika siswa diskalkulia kelas 5

\begin{tabular}{|c|c|c|c|c|c|}
\hline \multicolumn{2}{|c|}{ Kompetensi Dasar } & Indikator & \multirow{2}{*}{$\begin{array}{l}\text { Bentuk } \\
\text { Soal } \\
\text { Uraian }\end{array}$} & \multirow{2}{*}{$\frac{\text { No Soal }}{1}$} & \multirow{2}{*}{$\begin{array}{l}\text { Kesulitan } \\
\text { Belajar (KB) } \\
\text { K1 }\end{array}$} \\
\hline \multirow[t]{6}{*}{3.7} & Menjelaskan data yang & menjelaskan pengertian data & & & \\
\hline & berkaitan dengan diri murid & 3.7.2 membedakan data dan bukan data & & 2 & $\mathrm{~K} 2$ \\
\hline & atau lingkungan sekitar & 3.7.3 memberi contoh data diri siswa & & 3 & $\mathrm{~K} 3$ \\
\hline & serta cara menghimpun nya & dan data lingkungan sekitar & & & \\
\hline & & $\begin{array}{l}\text { 3.7.4 membedakan cara pengumpulan } \\
\text { data langsung dan tidak langsung }\end{array}$ & & 4 & K4 \\
\hline & & 3.7.5 menjelaskan manfaat data & & 5 & K5 \\
\hline \multirow[t]{6}{*}{3.8} & Menjelaskan penyajian data & 3.8.1 membuat judul tabel dan diagram & & & \\
\hline & yang berkaitan dengan diri & 3.8.2 menyajikan tabel & & 6,7 & K6 \\
\hline & murid dan membanding kan & 3.8.3 menyajikan diagram garis, batang, & & 8 & K7 \\
\hline & dengan data dari lingkungan & dan gambar & & $9-11$ & K8 \\
\hline & sekitar dalam bentuk daftar, & 3.8.4. menafsirkan tabel & & & K9 \\
\hline & $\begin{array}{l}\text { tabel, diagram gambar } \\
\text { (piktogram), diagram } \\
\text { batang, atau diagram garis }\end{array}$ & $\begin{array}{l}\text { 3.8.5. menafsirkan diagram garis, } \\
\text { batang, dan gambar }\end{array}$ & & $12,1314,15$ & K10 \\
\hline
\end{tabular}

Hasil uji kesulitan belajar penyajian data sebelum implementasi desain didaktis pada 10 siswa diskalkulia di kelas 5A ditunjukkan pada Tabel 5.

Tabel 5. Hasil uji kesulitan belajar penyajian data siswa diskalkulia kelas 5A sebelum implementasi desain didaktis

\begin{tabular}{llll}
\hline Siswa & Skore & Kesulitan Belajar (KB) & Jumlah KB \\
\hline A & 60 & K7, K8, K9, dan K10 & 4 \\
B & 33 & K2,K3, K5, K7, K8, K9, dan K10 & 7 \\
C & 44 & K2, K6, K8, K9, dan K10 & 5 \\
D & 35 & K1, K4, K6, K8, K9, dan K10 & 6 \\
E & 38 & K4, K6, K8, K9, dan K10 & 5 \\
F & 45 & K6, K7, K8, K9, dan K10 & 5 \\
G & 38 & K3, K6, K8, K9, dan K10 & 5 \\
H & 60 & K7, K8, K9, dan K10 & 4 \\
I & 38 & K4, K6, K8, K9, dan K10 & 5 \\
J & 33 & K2, K3, K5, K7, K8, K9, dan K10 & 7 \\
\hline Rata & 42,4 & & \\
\hline
\end{tabular}


Hasil uji kesulitan belajar penyajian data siswa diskalkulia di kelas $5 \mathrm{~A}$ sebelum implementasi desain didaktis menyatakan bahwa nilai rata-rata pengetahuan siswa sebesar 42,2 dan masih di bawah KKM. Pada kelas 5A terdapat dua siswa dengan kesulitan belajar matematika rendah yaitu siswa $\mathrm{A}$ dan siswa $\mathrm{H}$, dan dua siswa dengan kesulitan belajar matematika tinggi yaitu siswa $\mathrm{B}$ dan siswa J. Dua siswa dengan kesulitan belajar tinggi dari 28 jumlah siswa di kelas $5 \mathrm{~A}$ atau terdapat 7,1\% dari siswa kelas 5A mengalami diskalkulia tinggi. Hasil identifikasi siswa diskalkulia di kelas 5A mendekati hasil penelitian di Sabah, Malaysia yaitu terdapat 5,5\% dari siswa SD menderita diskalkulia. Sejalan dengan itu terdapat sekitar 5\% anak usia SD di New York mengalami diskalkulia. Dengan kata lain, setidaknya satu siswa menderita diskalkulia di setiap kelas yang berisi 30 anak (Hannell 2013).

Jumlah kesulitan belajar penyajian data dari 10 siswa diskalkulia kelas 5A antara 4-7 item. Siswa A dan $\mathrm{H}$ memiliki kesulitan belajar matematika rendah karena didukung oleh bimbingan orangtua di rumah sedangkan siswa B dan J memiliki kesulitan belaja matematika tinggi karena kurang perhatian orangtua di rumah. Kedua orangtua bekerja dan meninggalkan anaknya sendiri di rumah, tidak ada yang membimbing di rumah. Permasalahan ekonomi mempengaruhi kesulitan belajar matematika siswa secara tidak langsung. Keadaan keluarga yang tidak menunjang anak dalam belajar akan menyebabkan anak sulit dalam belajar seperti masalah ekonomi yang menyebabkan kedua orangtua meninggalkan anaknya di rumah untuk bekerja. Kesulitan belajar penyajian data terbanyak pada siswa diskalkulia adalah membuat judul tabel/diagram, menyajikan tabel/diagram, dan menafsirkan tabel/diagram.

Pada tahap antisipasi didaktis dan pedagogis dianalisis materi penyajian data untuk siswa diskalkulia sesuai kurikulum 2013 mata pelajaran matematika dengan kompetensi dasar 3.7 dan 4.7 serta 3.8 dan 4.8 yang tercantum pada Tabel 5. Materi penyajian data untuk siswa diskalkulia disamakan dengan siswa lainnya karena materinya esensial dalam kehidupan sehari-hari yaitu pengertian data, contoh data, cara pengumpulan data, tabel, diagram garis, diagram batang, dan diagram gambar. Tujuan pembelajaran untuk siswa diskalkulia dibuat lebih rendah dibandingkan siswa lainnya yaitu pada ranah kognitif rendah seperti mengingat, memahami, dan menerapkan, pada ranah afektif rendah seperti menerima dan merespon, dan pada ranah psikomotor rendah seperti meniru dan manipulasi. Setelah uji kesulitan belajar penyajian data untuk siswa diskalkulia sebelum implementasi desain didaktis dibuat dan dianalisis, guru membuat RPP dan power point (PPT) adaptif (sesuai kebutuhan siswa diskalkulia) dan instrumen penilaian dengan aplikasi quiziiz, wordwall, dan kahoot, agar siswa tertarik menjawabnya dan dapat dilakukan secara daring. Instrumen tersebut diberikan di akhir google meet, untuk melihat bagaimana siswa telah mencapai tujuan pembelajaran sesuai dengan pembelajaran daring yang dilakukan. Rencana Pelaksanaan Pembelajaran adaptif ditunjukkan pada Tabel 6.

Tabel 6. Rencana pelaksanaan pembelajaran adaptif penyajian data kelas 5

\begin{tabular}{|c|c|c|c|}
\hline Komponen & $\begin{array}{l}\text { Pengenalan Data } \\
\text { Google meet 1-2 }\end{array}$ & $\begin{array}{l}\text { Penyajian Data } \\
\text { Google meet 3-4 }\end{array}$ & $\begin{array}{l}\text { Penafsiran Data } \\
\text { Google meet 5-8 }\end{array}$ \\
\hline Tujuan & $\begin{array}{l}\text { 1. Melalui tanya jawab, } \\
\text { siswa dapat menjelaskan } \\
\text { pengertian data } \\
\text { 2. Melalui melihat gambar, } \\
\text { siswa dapat menunjukan } \\
\text { contoh data diri peserta didik } \\
\text { dan data lingkungan peserta } \\
\text { didik } \\
\text { 3. Melalui pengamatan video, } \\
\text { siswa dapat menerangkan } \\
\text { dan menghimpun data secara } \\
\text { langsung dan tidak langsung }\end{array}$ & $\begin{array}{l}\text { 1. Melalui pengamatan contoh, } \\
\text { siswa dapat menyajikan tabel } \\
\text { 2. Melalui pengamatan contoh, } \\
\text { siswa dapat menyajikan } \\
\text { diagram garis } \\
\text { 3. Melalui pengamatan contoh, } \\
\text { siswa dapat menyajikan } \\
\text { diagram batang } \\
\text { 4. Melalui pengamatan contoh, } \\
\text { siswa dapat menyajikan } \\
\text { diagram gambar } \\
\text { 5. Melalui tanya jawab, siswa } \\
\text { dapat menjelaskan hidup } \\
\text { manusia bagaikan diagram }\end{array}$ & $\begin{array}{l}\text { 1. Melalui pengamatan contoh, } \\
\text { siswa dapat menentukan data } \\
\text { tertinggi } \\
\text { 2. Melalui pengamatan contoh, } \\
\text { siswa dapat menentukan data } \\
\text { terendah } \\
\text { 3. Melalui pengamatan contoh, } \\
\text { siswa dapat menentukan jumlah } \\
\text { data } \\
\text { 4. Melalui pengamatan contoh, } \\
\text { siswa dapat menentukan selisih } \\
\text { data } \\
\text { 5. Melalui pengamatan contoh, } \\
\text { siswa dapat menentukan data } \\
\text { lebih besar atau lebih kecil }\end{array}$ \\
\hline
\end{tabular}




\begin{tabular}{|c|c|c|c|}
\hline Komponen & $\begin{array}{l}\text { Pengenalan Data } \\
\text { Google meet 1-2 }\end{array}$ & $\begin{array}{l}\text { Penyajian Data } \\
\text { Google meet 3-4 }\end{array}$ & $\begin{array}{l}\text { Penafsiran Data } \\
\text { Google meet 5-8 }\end{array}$ \\
\hline Pendahuluan & $\begin{array}{l}\text { 1. Guru mengecek kehadiran } \\
\text { siswa kelas } 5 A \\
\text { 2. Guru memotivasi siswa } \\
\text { terutama siswa diskalkulia } \\
\text { 3. Berdoa dipimpin salah satu } \\
\text { siswa diskalkulia } \\
\text { 4. Bernyanyi lagu wajib dipimpin } \\
\text { salah satu siswa diskalkulia } \\
\text { 5. Guru menanyakan materi } \\
\text { sebelumnya } \\
\text { 6. Guru menyampaikan tujuan } \\
\text { pembelajaran dan penilaian } \\
\text { 7. Kesepakatan kelas } \\
\text { 8. Siswa menjawab pretest } \\
\text { dengan aplikasi wordwall. }\end{array}$ & $\begin{array}{l}\text { 1. Guru mengecek kehadiran } \\
\text { siswa kelas } 5 \mathrm{~A} \\
\text { 2. Guru memotivasi siswa } \\
\text { terutama siswa diskalkulia } \\
\text { 3. Berdoa dipimpin salah satu } \\
\text { siswa diskalkulia } \\
\text { 4. Bernyanyi lagu wajib dipimpin } \\
\text { salah satu siswa diskalkulia } \\
\text { 5. Guru menanyakan materi } \\
\text { sebelumnya } \\
\text { 6. Guru menyampaikan tujuan } \\
\text { pembelajaran dan penilaian } \\
\text { 7. Kesepakatan kelas } \\
\text { 8. Siswa menjawab pretest } \\
\text { dengan aplikasi quizizz }\end{array}$ & $\begin{array}{l}\text { 1. Guru mengecek kehadiran siswa } \\
\text { kelas } 5 \mathrm{~A} \\
\text { 2. Guru memotivasi siswa terutama } \\
\text { siswa diskalkulia } \\
\text { 3. Berdoa dipimpin salah satu siswa } \\
\text { diskalkulia } \\
\text { 4. Bernyanyi lagu wajib dipimpin } \\
\text { salah satu siswa diskalkulia } \\
\text { 5. Guru menanyakan materi } \\
\text { sebelumnya } \\
\text { 6. Guru menyampaikan tujuan } \\
\text { pembelajaran dan penilaian } \\
\text { 7. Kesepakatan kelas } \\
\text { 8. Siswa menjawab pretest dengan } \\
\text { aplikasi kahoot }\end{array}$ \\
\hline Inti & $\begin{array}{l}\text { 1. Siswa mengamati data } \\
\text { peserta didik dan lingkungan } \\
\text { peserta didik dari guru } \\
\text { 2. Siswa merenungkan data } \\
\text { peserta didik dan lingkungan } \\
\text { peserta didik yang dimiliki } \\
\text { di rumah lalu ditulis dan } \\
\text { dikomunikasikan saat google } \\
\text { meet } \\
\text { 3. Murid dan guru berdiskusi } \\
\text { tentang kegunaan data } \\
\text { peserta didik dan lingkungan } \\
\text { peserta didik } \\
\text { 4. Murid dan guru } \\
\text { mendiskusikan bagaimana } \\
\text { cara menghimpun data }\end{array}$ & $\begin{array}{l}\text { 1. Siswa mengamati ceramah } \\
\text { guru tentang cara membuat } \\
\text { judul tabel/ diagram dan cara } \\
\text { menyajikannya (PPT dan } \\
\text { video) } \\
\text { 2. Siswa membuat judul tabel/ } \\
\text { diagram } \\
\text { 3. Siswa menyajikan tabel/ } \\
\text { diagram garis, batang, } \\
\text { gambar di buku tulis dan } \\
\text { fotonya dikirim ke classroom } \\
\text { 4. Guru memberi materi } \\
\text { tambahan tentang sumbu } \\
\text { tegak dan sumbu mendatar } \\
\text { serta teknik menggambar } \\
\text { objek pada diagram gambar. } \\
\text { 5. Murid dan guru berdiskusi } \\
\text { mengenai kegunaan tabel/ } \\
\text { diagram dalam kehidupan } \\
\text { sehari-hari }\end{array}$ & $\begin{array}{l}\text { 1. Siswa mengamati ceramah guru } \\
\text { tentang cara menafsirkan suatu } \\
\text { tabel/ diagram ke dalam kalimat } \\
\text { berita } \\
\text { 2. Guru memberi materi tambahan } \\
\text { tentang cara membuat kalimat } \\
\text { yang efektif } \\
\text { 3. Siswa menafsirkan suatu tabel/ } \\
\text { diagram dari guru di buku tulis } \\
\text { dan fotonya dikirim ke classroom } \\
\text { 4. Murid dan guru berdiskusi } \\
\text { mengenai kegunaan analisis dari } \\
\text { suatu tabel/ diagram }\end{array}$ \\
\hline Penutup & $\begin{array}{l}\text { 1. Siswa menyimpulkan materi } \\
\text { yang telah diberikan berupa } \\
\text { peta konsep di buku tulis dan } \\
\text { fotonya kirim ke classroom } \\
\text { 2. Guru merespon kesimpulan } \\
\text { siswa } \\
\text { 3. Siswa menjawab postest } \\
\text { dengan aplikasi wordwall } \\
\text { 4. Siswa dan guru membahas } \\
\text { postest } \\
\text { 5. Guru memberi penguatan } \\
\text { 6. Guru memberitahu materi } \\
\text { berikutnya } \\
\text { 7. Siswa dan guru merayakan } \\
\text { keberhasilan pembelajaran } \\
\text { dengan permainan/ tiktok/ } \\
\text { menggambar ekspresi/ } \\
\text { bernyanyi/ menari } \\
\text { 8. Refleksi siswa dan guru } \\
\text { 9. Berdoa dipimpin siswa } \\
\text { diskalkulia }\end{array}$ & $\begin{array}{l}\text { 1. Siswa menyimpulkan materi } \\
\text { yang telah diberikan berupa } \\
\text { peta konsep di buku tulis dan } \\
\text { fotonya kirim ke classroom } \\
\text { 2. Guru merespon kesimpulan } \\
\text { siswa } \\
\text { 3. Siswa menjawab postest } \\
\text { dengan aplikasi quizziz } \\
\text { 4. Siswa dan gurumembahas } \\
\text { postest } \\
\text { 5. Guru memberi penguatan } \\
\text { 6. Guru memberitahu materi } \\
\text { berikutnya } \\
\text { 7. Siswa dan guru merayakan } \\
\text { keberhasilan pembelajaran } \\
\text { dengan permainan/ tiktok/ } \\
\text { menggambar ekspresi/ } \\
\text { bernyanyi/ menari } \\
\text { 8. Refleksi siswa dan guru } \\
\text { 9. Berdoa dipimpin siswa } \\
\text { diskalkulia }\end{array}$ & $\begin{array}{l}\text { 1. Siswa menyimpulkan materi } \\
\text { yang telah diberikan berupa peta } \\
\text { konsep di buku tulis dan fotonya } \\
\text { kirim ke google classroom } \\
\text { 2. Guru merespon kesimpulan siswa } \\
\text { 3. Siswa menjawab postest dengan } \\
\text { aplikasi kahoot } \\
\text { 4. Siswa dan gurumembahas } \\
\text { postest } \\
\text { 5. Guru memberi penguatan } \\
\text { 6. Guru memberitahu materi } \\
\text { berikutnya } \\
\text { 7. Siswa dan guru merayakan } \\
\text { keberhasilan pembelajaran } \\
\text { dengan permainan/ tiktok/ } \\
\text { menggambar ekspresi/ } \\
\text { bernyanyi/ menari } \\
\text { 8. Refleksi siswa dan guru } \\
\text { 9. Berdoa dipimpin siswa diskalkulia }\end{array}$ \\
\hline
\end{tabular}




\begin{tabular}{|c|c|c|c|}
\hline Komponen & $\begin{array}{l}\text { Pengenalan Data } \\
\text { Google meet 1-2 }\end{array}$ & $\begin{array}{l}\text { Penyajian Data } \\
\text { Google meet 3-4 }\end{array}$ & $\begin{array}{l}\text { Penafsiran Data } \\
\text { Google meet 5-8 }\end{array}$ \\
\hline \multirow{3}{*}{ Penilaian } & $\begin{array}{l}\text { 1. Sikap: observasi sikap selama } \\
\text { google meet (keaktifan, } \\
\text { disiplin tugas) }\end{array}$ & $\begin{array}{l}\text { 1. Sikap: observasi sikap selama } \\
\text { google meet (keaktifan, } \\
\text { disiplin tugas) }\end{array}$ & $\begin{array}{l}\text { 1. Sikap: observasi sikap selama } \\
\text { google meet (keaktifan, disiplin } \\
\text { tugas) }\end{array}$ \\
\hline & $\begin{array}{l}\text { 2. Pengetahuan: tes online } 10 \\
\text { PG dengan aplikasi wordwall }\end{array}$ & $\begin{array}{l}\text { 2. Pengetahuan: tes online } 10 \text { PG } \\
\text { dengan aplikasi quizziz }\end{array}$ & $\begin{array}{l}\text { 2. Pengetahuan: tes online } 10 \text { PG } \\
\text { dengan aplikasi kahoot }\end{array}$ \\
\hline & $\begin{array}{l}\text { 3. Keterampilan: Membuat peta } \\
\text { konsep kesimpulan }\end{array}$ & $\begin{array}{l}\text { 3. Keterampilan: Membuat peta } \\
\text { konsep kesimpulan }\end{array}$ & $\begin{array}{l}\text { 3. Keterampilan: Membuat peta } \\
\text { konsep kesimpulan }\end{array}$ \\
\hline
\end{tabular}

Pada tahap metapedadidaktik diimplementasikan desain didaktis selama delapan kali pertemuan di google meet dengan materi dapat ditunjukkan pada Tabel 7.

Tabel 7. Link Google meet Pembelajaran Penyajian Data Kelas 5A

\begin{tabular}{lll}
\hline Pertemuan ke- & Waktu & Materi \\
\hline 1 & 2 Maret 2021 & Pengenalan data \\
2 & 12 Maret 2021 & Membaca data \\
3 & 18 Maret 2021 & $\begin{array}{l}\text { Penyajian tabel, diagram garis, } \\
\text { diagram batang }\end{array}$ \\
4 & 25 Maret 2021 & Penyajian diagram gambar \\
5 & 8 April 2021 & Menafsirkan tabel \\
6 & 16 April 2021 & Menafsirkan diagram garis \\
7 & 7 Mei 2021 & Menafsirkan diagram batang \\
8 & 25 Mei 2021 & Menafsirkan diagram gambar \\
\hline
\end{tabular}

Selama google meet terjadi situasi aksi, situasi formulasi, situasi validasi, dan situasi institusionalisasi. Situasi aksi tergambar saat siswa diskalkulia menemukan sendiri pengertian data, perbedaan data dan bukan data, menunjukkan dokumen-dokumen di rumah, mana data diri siswa dan mana data lingkungan siswa, menjelaskan cara mengumpulkan data secara langsung dan tidak langsung, menggambar tabel/diagram dengan penggaris, membuat judul tabel/diagram dengan kalimat yang efektif, membuat penafsiran sebuah tabel/diagram dengan kalimat berita yang efektif. Situasi formulasi tergambar saat siswa diskalkulia bertanya jawab dengan temannya dan menanggapi respon gurunya atau temannya dalam google meet. Situasi validasi tergambar saat guru memberi konfirmasi atas tanggapan/respon jawaban siswa. Guru membimbing siswa diskalkulia yang mengalami kesulitan dalam membaca data berupa tabel/diagram saat google meet. Guru memberi dukungan belajar untuk mendorong siswa diskalkulia agar dapat belajar secara mandiri (tidak selalu tergantung pada bimbingan orangtua). Situasi institusionalisasi tergambar saat siswa diskalkulia dapat menjawab soal lain dari guru atau menjawab soal lain dari temannya atau menjawab kuis online di akhir pembelajaran dengan pengetahuan yang baru saja diperolehnya.

Pada google meet pengenalan data, siswa diskalkulia dapat menyebutkan pengertian data, perbedaan data dan bukan data, contoh data diri siswa dan data lingkungan sekitar, cara pengumpulan data secara langsung dan tidak langsung. Ketika guru menanyakan manfaat dokumen-dokumen asli yang dimiliki setiap keluarga siswa seperti KTP, rapot, akte kelahiran, kartu keluarga, ATM, piagam penghargaan, data pekerjaan orangtua, data barang-barang di kelas, siswa sulit menjelaskan manfaat dokumen-dokumen tersebut dengan lancar. Oleh karena itu guru perlu berkolaborasi dengan orangtua untuk membantu memberi penjelasan kepada anaknya tentang manfaat dokumen-dokumen tersebut yang ada di rumah.

Pada google meet penyajian data, siswa diskalkulia masih sulit menyajikan tabel atau diagram garis/batang/gambar dengan baik. Ketika guru menjelaskan sumbu x dan sumbu y untuk menyajikan diagram, awalnya siswa masih sulit membedakan kedua sumbu. Oleh karena itu guru perlu memberi penguatan materi sumbu $x$ dan sumbu y dimana sumbu $x$ menggambarkan data kategori dan sumbu y menggambarkan data frekuensi kepada siswa, agar siswa tidak terbalik meletakkannya. Ketika guru 
menyuruh siswa diskalkulia memberi judul pada sebuah tabel/diagram, siswa masih sulit menuliskan judul dengan efektif. Oleh karena itu guru perlu memberi contoh lebih banyak tentang cara membuat judul tabel/diagram yang efektif dan sesuai keterangan data yang diberikan. Dalam membuat judul tabel/diagram, siswa diskalkulia belum bisa menulis judul yang efektif dan benar sesuai kaidah bahasa Indonesia, seperti yang ditunjukkan pada Gambar 2.

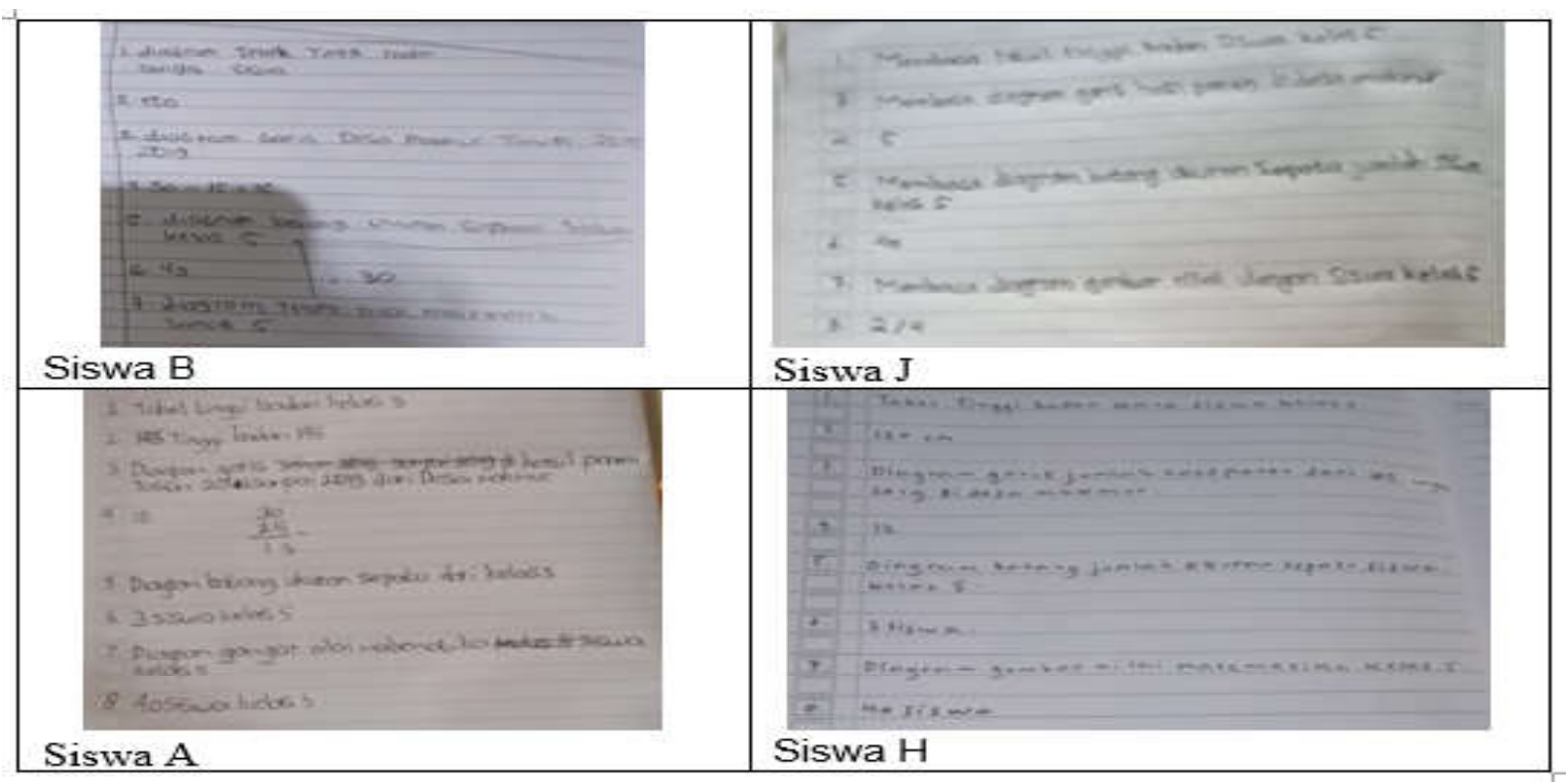

Gambar 2. Contoh kesulitan belajar siswa diskalkulia dalam pembuatan judul tabel/diagram

Dari Gambar 2 beberapa kesulitan siswa diskalkulia kelas 5 dalam membuat judul tabel/diagram sebagai berikut: (1) judul ditulis kurang efektif (siswa $\mathrm{B}, \mathrm{J}, \mathrm{A}$, dan $\mathrm{H}$ ); (2) penulisan judul belum benar sesuai kaidah bahasa Indonesia yaitu siswa belum menulis huruf kapital di setiap awal kata (siswa $B$, J, A, dan H); (3) judul ditulis terlalu kecil (siswa J dan H); (4) judul terdapat coretan (siswa A), dan (5) Tidak mencantumkan satuan pengukuran pada judul (siswa $B, J, A$, dan $H$ ). Untuk mengatasi kesulitan tersebut, guru perlu memberi tambahan materi penulisan judul yang efektif dan benar sesuai kaidah bahasa Indonesia kepada siswa diskalkulia melalui pekerjaan rumah (PR) bekerjasama dengan orangtua.

Dalam menyajikan tabel/diagram, siswa diskalkulia belum bisa membuat tabel/ diagram yang rapi sebagaimana dapat dilihat di Gambar 3.

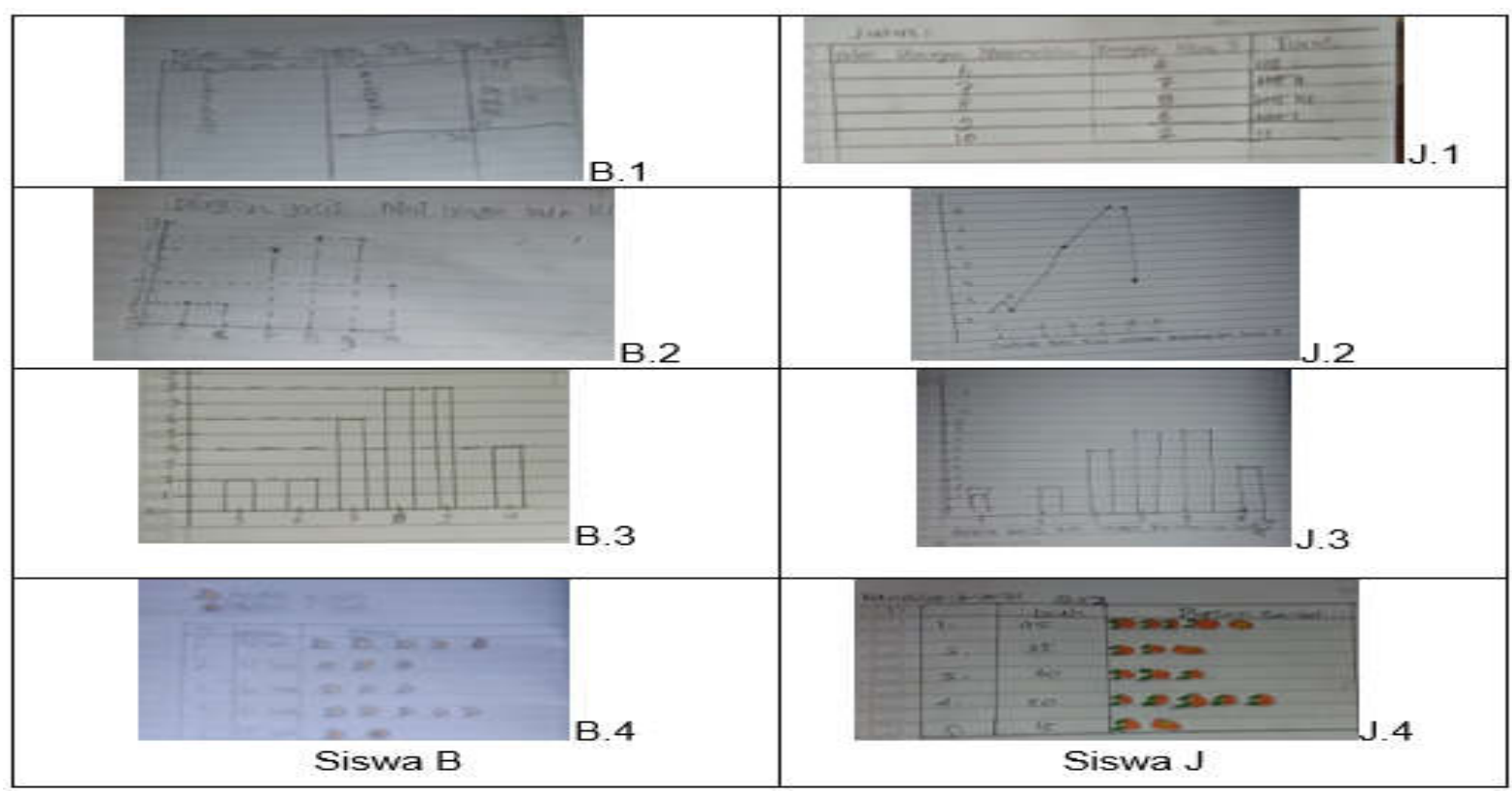




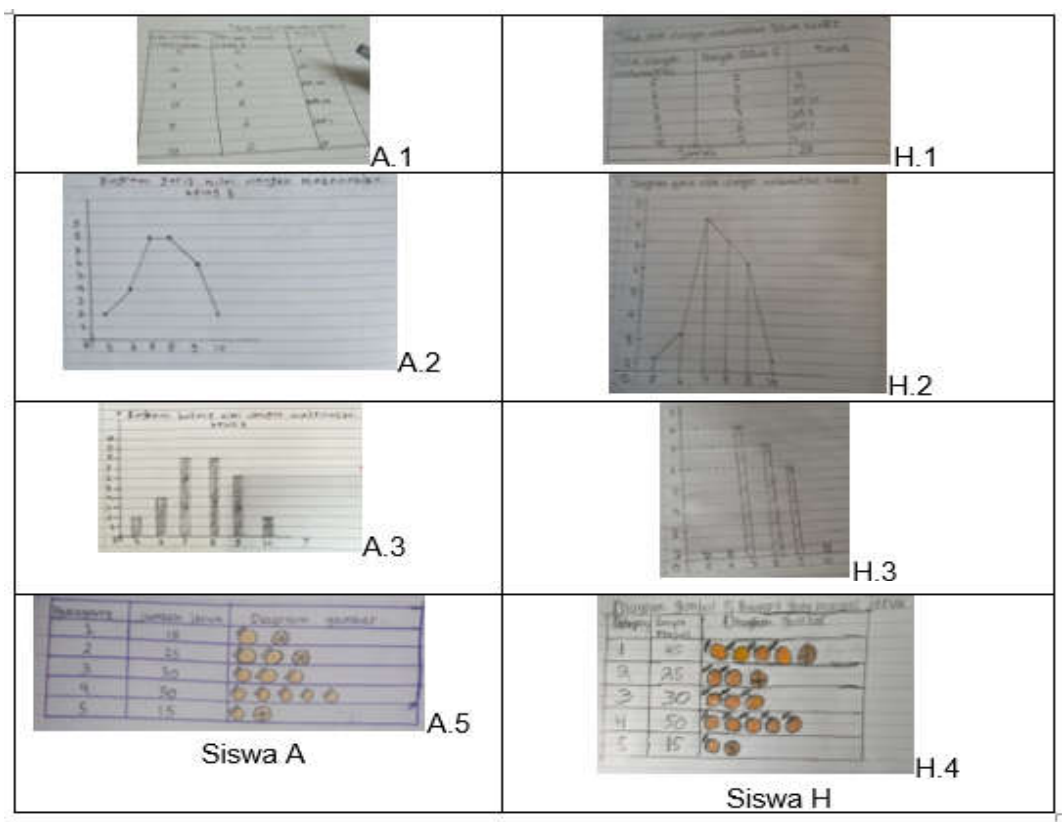

Gambar 3. Contoh kesulitan belajar siswa diskalkulia dalam penyajian tabel/diagram

Dari Gambar 3 beberapa kesulitan siswa diskalkulia kelas 5 dalam menyajikan tabel adalah sebagai berikut: (1) tabel tidak dibuat dengan penggaris akibatnya tabel tidak lurus (B.1); (2) tidak menuliskan judul tabel (J.1); (3) Kesalahan penulisan turus yaitu 3 ditulis III (A.1); (4) tabel yang dibuat kurang 1 baris (J.1); dan (5) banyak siswa di soal dengan di tabel tidak sama (H.1).

Dari Gambar 3 beberapa kesulitan siswa diskalkulia kelas 5 dalam menyajikan diagram garis adalah sebagai berikut: (1) diagram garis berupa titik-titik saja, tidak dibuatkan garisnya (B.2); (2) tidak mencantumkan keterangan sumbu $x$ dan sumbu y (A.2, B.2, J.2, dan H.2); (3) belum bisa menentukan titik koordinat dengan benar (J.2); (4) interval angka pada sumbu $\mathrm{x}$ dan sumbu y tidak sama (A.2, B.2, dan J.2); serta (5) diagram garis tidak dibuat dengan penggaris akibatnya diagram garis tidak lurus (B.2 dan J.2).

Dari Gambar 3 beberapa kesulitan siswa diskalkulia kelas 5 dalam menyajikan diagram batang adalah sebagai berikut: (1) tidak mencantumkan keterangan sumbu $x$ dan sumbu y (A.3, B.3, J.3, dan H.3); (2) belum menuliskan judul diagram batang (B.3, J.3, dan H.3); (3) interval angka pada sumbu $x$ dan sumbu y tidak sama sehingga lebar batang tidak sama (A.3, B.3, dan J.3); serta (4) diagram batang tidak dibuat dengan penggaris akibatnya diagram batang tidak lurus (J.3).

Dari Gambar 3 beberapa kesulitan siswa diskalkulia kelas 5 dalam menyajikan diagram gambar adalah sebagai berikut: (1) diagram gambar tidak dibuat dengan penggaris akibatnya diagram gambar tidak lurus (A.4 dan H.4); (2) tidak menuliskan judul (A.4, B.4, dan J.4); (3) tidak membuat keterangan gambar (A.4, J.4, dan H.4); serta (4) gambar pada diagram berbeda-beda dan banyak yang tidak sama dengan keterangan gambar (A.4, B.4, J.4, dan H.4).

Untuk mengatasi kesulitan-kesulitan belajar penyajian data pada siswa diskalkulia, guru perlu memberi tambahan materi seperti penggunaan penggaris, konsep sumbu $\mathrm{x}$ dan sumbu $\mathrm{y}$, serta cara menggambar objek yang sederhana dan mudah dibuat siswa. Untuk keterangan pada diagram gambar melalui PR dilakukan bekerjasama dengan orangtua. Sebagai contoh menggambar orang bisa disimbolkan dengan bulatan yang diberi mata, menggambar buah bisa disimbolkan dengan bulatan yang diberi warna sesuai warna asli buah. Selain itu, guru dapat menginstruksikan penggunaan buku kotak-kotak kepada siswa diskalkulia saat penyajian tabel/diagram. Buku kotak-kotak dapat membantu siswa diskalkulia membuat sajian tabel/diagram yang rapi dan interval nilai pada sumbu $x$ dan sumbu y yang sama. Untuk mengatasi siswa diskalkulia yang sering lupa memberi keterangan sumbu $x$ dan sumbu y pada diagram, guru perlu menambahkan perintah pada soal untuk menuliskan keterangan sumbu $x$ dan sumbu $y$.

Pada google meet penafsiran data, siswa diskalkulia sulit menuliskan penafsiran tabel dengan kalimat yang efektif sebagaimana diperlihatkan di Gambar 4. 


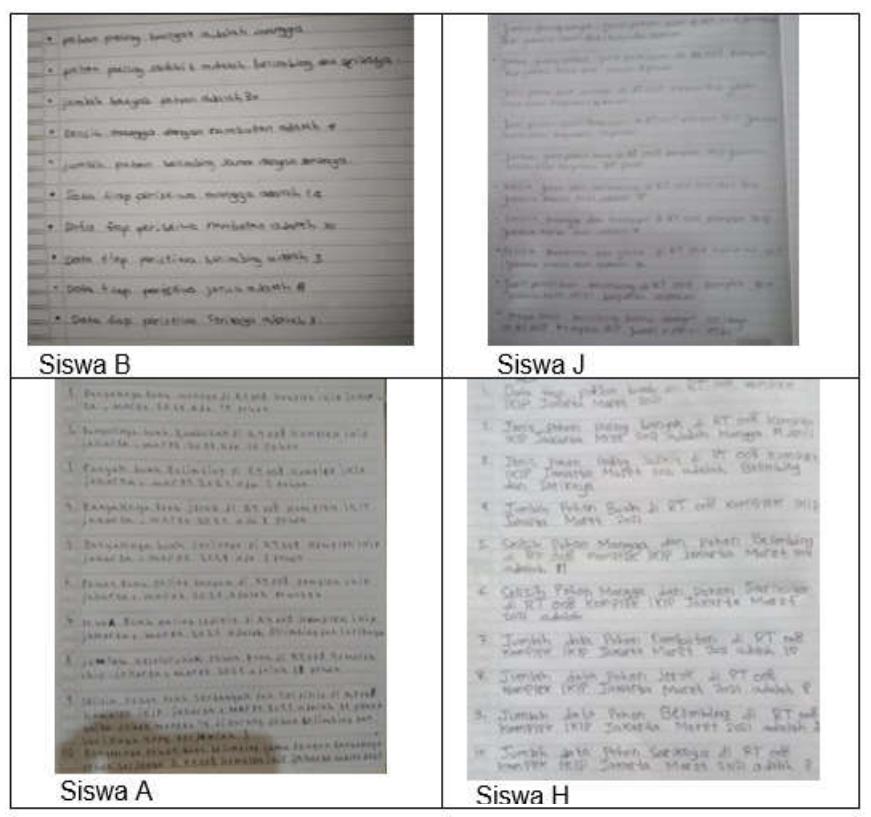

Gambar 4. Contoh kesulitan belajar siswa diskalkulia dalam penafsiran tabel

Dari Gambar 4 beberapa kesulitan siswa diskalkulia kelas 5 dalam menafsirkan tabel sebagai berikut: (1) siswa B menafsirkan tabel sudah berupa kalimat berita tetapi kalimatnya terlalu singkat hingga menimbulkan makna lain; (2) siswa A dan J menafsirkan tabel sudah berupa kalimat berita tetapi penafsirannya membuat pembaca bingung antara jumlah pohonnya atau jumlah buahnya; dan (4) siswa $\mathrm{H}$ menafsirkan tabel sudah berupa kalimat berita tetapi kalimat penafsirannya kurang efektif, contohnya, penulisan 'jumlah data pohon rambutan ...', seharusnya, 'jumlah pohon rambutan ...'. Untuk mengatasi kesulitan tersebut guru perlu memberikan latihan menulis kalimat efektif saat pembelajaran bahasa Indonesia.

Pada google meet penafsiran data siswa diskalkulia sulit menuliskan penafsiran diagram garis dengan kalimat yang efektif, seperti ditunjukkan pada Gambar 5.

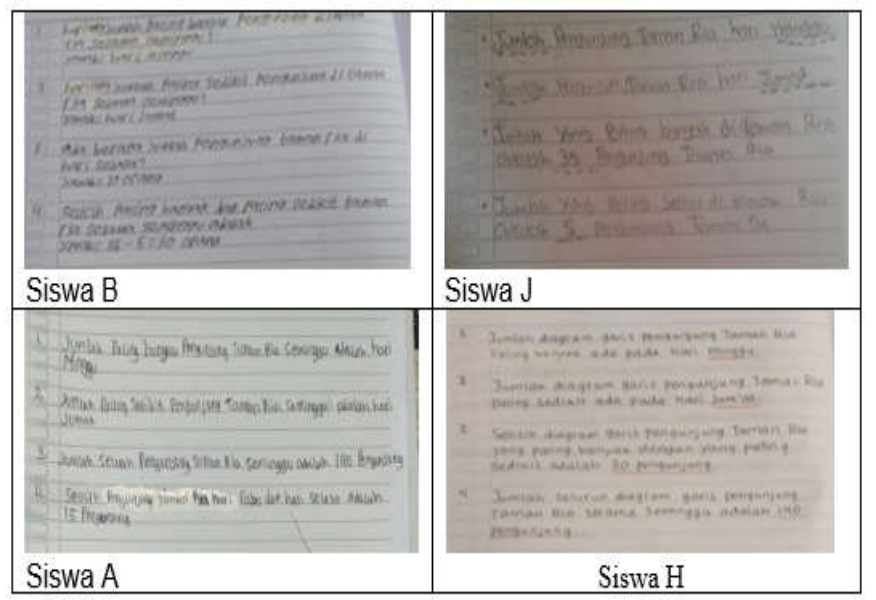

Gambar 5. Contoh kesulitan belajar siswa diskalkulia dalam penafsiran diagram garis

Dari Gambar 5 beberapa kesulitan siswa diskalkulia kelas 5 dalam menafsirkan diagram garis sebagai berikut: (1) siswa B belum dapat menafsirkan diagram garis ke dalam kalimat berita tapi menjadi kalimat tanya. Guru perlu memberi tambahan literasi membaca tiap hari kepada siswa diskalkulia untuk menambah kosa kata dan mengajarkan mereka perbedaan kalimat tanya dengan kalimat berita dan fungsi kedua kalimat tersebut melalui pembelajaran virtual dan PR kerjasama dengan orangtua; (2) siswa J menafsirkan diagram garis ke dalam kalimat berita yang tidak bermakna, contohnya jumlah pengunjung Taman Ria di hari minggu, jumlah yang paling banyak di Taman Ria adalah 35 pengunjung; (3) siswa A dan J menafsirkan diagram garis sudah berupa kalimat berita 
tetapi siswa masih sulit membedakan jumlah dengan waktu, contohnya 'Jumlah paling banyak pengunjung Taman Ria seminggu adalah hari Minggu, seharusnya: Hari Minggu adalah hari yang paling banyak dihadiri oleh pengunjung di Taman Ria; dan (4) kalimat penafsiran siswa $\mathrm{H}$ juga masih menyerupai kalimat judul, contohnya penulisan 'Jumlah seluruh diagram garis pengunjung Taman Ria selama seminggu adalah 140 pengunjung', seharusnya, 'Jumlah pengunjung Taman Ria selama seminggu adalah 140 orang'.

Pada google meet penafsiran data, siswa diskalkulia sulit menuliskan penafsiran diagram batang dengan kalimat yang efektif, seperti ditunjukkan pada Gambar 6.

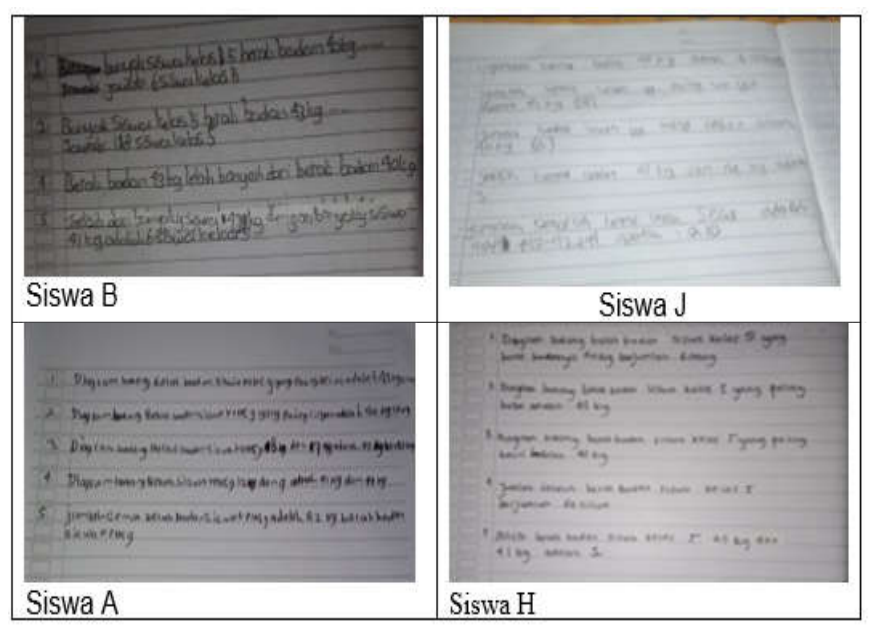

Gambar 6. Contoh kesulitan belajar siswa diskalkulia dalam penafsiran diagram batang

Dari Gambar 6 beberapa kesulitan siswa diskalkulia kelas 5 dalam menafsirkan diagram batang sebagai berikut: (1) siswa B belum dapat menafsirkan diagram batang ke dalam kalimat berita; (2) siswa J sudah dapat menafsirkan diagram batang ke dalam kalimat berita tetapi siswa tersebut masih sulit membedakan jumlah dengan berat, contohnya penulisan 'Jumlah berat badan yang paling banyak adalah 43 kg', seharusnya 'Berat badan siswa kelas 9 yang paling banyak adalah 43 kg'; (3) siswa $\mathrm{A}$ dan $\mathrm{H}$ menafsirkan diagram batang sudah berupa kalimat berita tetapi siswa masih sulit membedakan kalimat penafsiran dengan kalimat judul, contohnya penulisan 'Diagram batang berat badan siswa kelas 9 yang paling berat adalah $43 \mathrm{~kg}$, seharusnya, 'Berat badan siswa kelas 9 yang paling berat adalah 43 kg'. Untuk siswa diskalkulia yang masih salah menentukan jumlah, selisih, data lebih besar atau lebih kecil pada penafsiran data maka antisipasi yang dilakukan guru adalah dengan mencantumkan angka pada tiap titik diagram garis/ batang sehingga siswa diskalkulia tidak salah membaca angka pada diagram garis/batang dan dapat menghitung jumlah, selisih, dan membandingkan dengan mudah dan tepat.

Pada google meet penafsiran data, siswa diskalkulia sulit menuliskan penafsiran diagram gambar dengan kalimat yang efektif, seperti ditunjukkan pada Gambar 7.

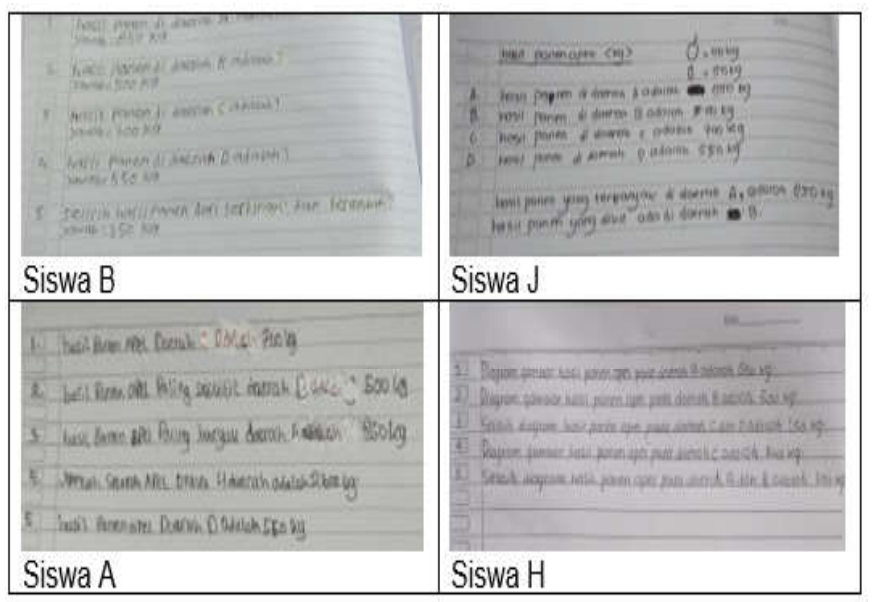

Gambar 7. Contoh kesulitan belajar siswa diskalkulia dalam penafsiran diagram gambar 
Dari Gambar 7 beberapa kesulitan siswa diskalkulia kelas 5 dalam menafsirkan diagram gambar sebagai berikut: (1) siswa B menafsirkan diagram gambar belum berupa kalimat berita; (2) Siswa A dan J menafsirkan diagram gambar sudah berupa kalimat berita tetapi tidak lengkap, banyak coretan, dan masih menggunakan kata tidak baku, juga penulisan 'Jumlah seluruh apel untuk 4 daerah adalah 2600 kg', tidak menyebutkan nama daerahnya dan kategori panen; serta (3) siswa $\mathrm{H}$ menafsirkan diagram gambar sudah berupa kalimat berita tetapi kalimat penafsirannya masih menyerupai kalimat judul, contohnya penulisan 'Diagram gambar hasil panen apel pada daerah A adalah $850 \mathrm{~kg}$ ' seharusnya 'Hasil panen apel pada daerah A adalah 850 kg'.

Berikut hasil penilaian penyajian data dengan aplikasi online pada akhir pertemuan virtual dalam mengimplementasikan desain didaktis yang telah dirancang, ditunjukkan pada Tabel 8.

Tabel 8. Nilai kuis penyajian data akhir pertemuan virtual saat implementasi desain didaktis siswa diskalkulia kelas 5

\begin{tabular}{cccc}
\hline Siswa & Pengenalan Data & Penyajian Data & Penafsiran Data \\
\hline A & 80 & 90 & 90 \\
B & 70 & 70 & 80 \\
C & 80 & 80 & 90 \\
D & 70 & 70 & 80 \\
E & 70 & 80 & 80 \\
F & 80 & 80 & 90 \\
G & 70 & 70 & 80 \\
H & 80 & 90 & 90 \\
I & 70 & 80 & 80 \\
J & 70 & 70 & 80 \\
\hline Rerata & 74 & 78 & 84 \\
\hline
\end{tabular}

Berdasarkan Tabel 8 terlihat nilai rata-rata penyajian data siswa diskalkulia pada akhir pertemuan virtual saat implementasi desain didaktis menunjukkan peningkatan yaitu di atas KKM. Artinya desain didaktis dapat meningkatkan hasil belajar penyajian data siswa diskalkulia kelas 5. Hasil penilaian kuis dapat membuktikan secara rata-rata keseluruhan siswa diskalkulia tidak berbeda dengan siswa nondiskalkulia. Siswa dengan kesulitan belajar tinggi (siswa B dan J) memiliki peningkatan hasil belajar sama dengan siswa dengan kesulitan belajar rendah (siswa $\mathrm{A}$ dan $\mathrm{H}$ ). Hal ini menunjukkan bahwa jika diberikan desain khusus (desain didaktis) maka siswa diskalkulia mampu menunjukkan hasil belajar sebaik siswa tidak diskalkulia.

Setelah implementasi desain didaktis dalam semua pertemuan virtual selesai, kesepuluh siswa diskalkulia mengisi uji kesulitan belajar penyajian data kembali dan hasilnya diperlihatkan di Tabel 9.

Tabel 9. Hasil uji kesulitan belajar penyajian data siswa diskalkulia kelas 5A setelah implementasi desain didaktis

\begin{tabular}{cccc}
\hline Siswa & Skore & Kesulitan Belajar (KB) & Jumlah KB \\
\hline A & 95 & K9 & 1 \\
B & 73 & K8, K9, dan K10 & 3 \\
C & 78 & K8 dan K10 & 2 \\
D & 88 & K8 dan K9 & 2 \\
E & 80 & K9 dan K10 & 2 \\
F & 78 & K8 dan K10 & 2 \\
G & 80 & K9 dan K10 & 2 \\
H & 93 & K8 & 1 \\
I & 80 & K8 dan K9 & 2 \\
J & 73 & K8, K9, dan K10 & 3 \\
\hline Rerata & 81,8 & & \\
\hline
\end{tabular}


Berdasarkan Tabel 9 hasil uji kesulitan belajar penyajian data siswa diskalkulia kelas 5A setelah implementasi desain didaktis diperoleh nilai rata-rata penyajian data sebesar 81,8 . Meningkatnya nilai rata-rata penyajian data siswa diskalkulia karena desain didaktis melibatkan aktivitas siswa diskalkulia saat pertemuan virtual. Guru memberi kesempatan siswa diskalkulia untuk bertanya, menjawab pertanyaan guru dan teman, memberi contoh data-data yang ada di rumah dan kegunaannya, mengeluarkan pendapat dari penafsiran tabel/diagram, berunjuk kerja seperti memimpin doa, memimpin bernyanyi, dan memberi hikmah dari penyajian data bagi kehidupan sehari-hari. Mereka dibuat sibuk, diikutsertakan dalam kegiatan kelas virtual, serta tidak didiamkan. Walau kemampuan mereka terbatas tapi guru tetap menunjuk mereka untuk melakukannya artinya yang banyak ditanya justru siswa-siswa diskalkulia. Guru bahkan memberi pujian kepada siswa diskalkulia yang tampil luar biasa. Meningkatnya nilai rata-rata penyajian data siswa diskalkulia juga dipengaruhi dari pemakaian PPT adaptif yang dirancang guru dalam setiap pertemuan virtual. Guru merancang PPT adaptif dengan memasukkan sintak-sintak didaktis dan pedagogis seperti kegiatan berdoa sebelum dan sesudah belajar, kegiatan menyanyikan lagu nasional/daerah/anak-anak, membuat kesepakatan kelas, hikmah pembelajaran, respon siswa melalui gambar berwarna, dan ice breaking yang disukai siswa seperti tebak perbedaan, teka-teki, tiktok, kuis online, dan senam sederhana. Diperlukan kemampuan mencairkan suasana bagi siswa diskalkulia dengan ice breaking seperti permainan, bergerak, dan menyanyikan lagu sehingga kekurangan mereka tidak terlihat menonjol. Oleh karena itu guru perlu menfasilitasi kegiatan belajar mengajarnya dengan berbagai metode dan media, halhal terbaru, dan yang disukai anak-anak. Memberi pujian kepada siswa diskalkulia yang tampil luar biasa saat pertemuan virtual atau dapat mengerjakan tugas tepat waktu dan lengkap, juga dapat mengurangi kesulitan belajar matematika. Siswa dengan dukungan hubungan interpersonal yang positif dari gurunya akan memiliki sikap dan nilai akademik lebih baik. Kesulitan belajar menyajikan data terbanyak ditemukan pada siswa diskalkulia dalam membuat judul tabel/diagram dan menyajikan tabel/diagram. Kemampuan keduanya memang memerlukan waktu untuk banyak berlatih pada siswa diskalkulia melalui PR kerjasama dengan orangtua.

Kegiatan restrosfektif dilakukan berdasarkan perbedaan hasil uji kesulitan belajar penyajian data siswa diskalkulia, sebelum dan sesudah implementasi desain didaktis, diperolehnya informasi bahwa telah terjadi penurunan kesulitan belajar pada kesepuluh siswa diskalkulia kelas 5A, ditunjukkan pada Tabel 10.

Tabel 10. Penurunan kesulitan belajar (KB) penyajian data siswa siskalkulia kelas 5A dengan desain didaktis

\begin{tabular}{ccccc}
\hline Siswa & Jumlah KB Awal & Jumlah KB Akhir & Penurunan KB & Persentase Penurunan (\%) \\
\hline A & 4 & 1 & 3 & 75 \\
B & 7 & 3 & 4 & 57 \\
C & 5 & 2 & 3 & 60 \\
D & 6 & 2 & 4 & 67 \\
E & 5 & 2 & 3 & 60 \\
F & 5 & 2 & 3 & 60 \\
G & 5 & 2 & 3 & 60 \\
H & 4 & 1 & 3 & 75 \\
I & 5 & 2 & 3 & 60 \\
J & 7 & 3 & 4 & 57 \\
\hline Rerata nilai & & & & 63,1 \\
\hline
\end{tabular}

Berdasar Tabel 10 hasil penelitian menyimpulkan bahwa kesepuluh siswa diskalkulia kelas 5A mengalami penurunan kesulitan belajar setelah mengimplementasikan desain didaktis pada pembelajaran penyajian data rata-rata sebesar $63,1 \%$. Kesepuluh siswa diskalkulia kelas $5 \mathrm{~A}$ sudah mampu menguasai materi penyajian data dan desain didaktis yang telah peneliti susun dapat menurunkan kesulitan belajar penyajian data siswa diskalkulia kelas 5A. 
Penurunan kesulitan belajar terbesar terjadi pada siswa $\mathrm{A}$ dan $\mathrm{H}$ sebesar $75 \%$ karena dukungan orangtua yang sangat besar pada anaknya. Penurunan kesulitan belajar terkecil terjadi pada siswa B dan J sebesar 57\% karena dukungan orangtua yang sangat kecil pada anaknya. Orangtua siswa $\mathrm{B}$ dan J bekerja di luar rumah sehingga mereka harus meninggalkan anaknya sendiri di rumah saat anak sedang melakukan pembelajaran jarak jauh (PJJ) dari pagi hingga tengah hari. Anak harus mengerjakan sendiri tugas PJJ dari google classroom atau mengerjakan sendiri tugas guru selama google meet berlangsung. Kedua contoh ini memberikan fakta bahwa ada pengaruh peran orangtua di rumah terhadap kemudahan belajar matematika siswa di rumah selama PJJ. Orang tua memiliki peran penting dalam PJJ anak di rumah. Orang tua yang selalu memberi perhatian pada kegiatan PJJ anak di rumah akan membuat anak lebih bersemangat dalam belajar karena anak mendapat figur untuk bertanya dan menjawab segala kesulitan belajar yang dihadapi saat itu dan memperoleh arahan saat menyelesaikan tugas dari guru. Menurut Winingsih (2020) terdapat empat peran orang tua selama PJJ yaitu: (1) sebagai guru di rumah; (2) sebagai penyedia sarana dan prasarana belajar di rumah; (3) sebagai pemberi semangat dan dukungan belajar; dan (4) sebagai model pembelajar sejati pada anaknya.

Dari hasil wawancara terungkap bahwa orang tua siswa dengan diskalkulia yang memiliki masalah ekonomi ternyata lebih memiliki kesempatan lebih kecil untuk mendampingi anaknya. Terbukti dengan beberapa fakta yaitu ibu siswa lebih memilih meninggalkan anaknya karena harus membiayai kebutuhan keluarga termasuk kuota internet (ibu siswa B). Hal lain yang terungkap adalah kuota internet terpaksa dialokasikan untuk kebutuhan kepala keluarga sebagai pengojek (ibu siswa J). Hal ini berlawanan dengan keluarga yang terlihat mendukung yaitu orang tua belajar pada guru anaknya tentang cara menyelesaikan tugas-tugas darinya dan mengijinkan anak untuk kerja kelompok ke rumah temannya yang pintar (ibu siswa A). Hal lain yang terungkap adalah walau kedua orang tua kerja tapi tetap memantau PJJ anak dari HP pada waktu yang telah direncanakan bersama dan bertanya pada anak tiap malam apa yang belum dipahaminya. Jika anak belum paham maka orangtua menghubungi guru anak untuk berkolaborasi menyelesaikan masalah anak (ibu siswa $\mathrm{H}$ ). Jadi peran orang tua dalam mengatasi kesulitan belajar matematika siswa diskalkulia sangat penting. Orang tua harus selalu mengingatkan anaknya akan tugas PJJ, menfasilitasi sarana prasarana belajar anak, memantau PJJ anak, dan berkolaborasi dengan guru jika menemui masalah PJJ.

Dari penelitian ini desain didaktis dapat dimanfaatkan untuk mengatasi kesulitan belajar matematika siswa diskalkulia sekaligus meningkatkan hasil belajar siswa materi penyajian data karena proses pembelajarannya dirancang dari kesulitan belajar siswa. Kesulitan belajar tidak dapat dihilangkan bagi siswa diskalkulia tapi dapat diturunkan karena mereka memiliki gangguan neurologi yang membutuhkan waktu untuk diulang-ulang hingga menjadi sebuah kebiasaan. Mereka juga membutuhkan dukungan orangtua yang sabar dan inovatif untuk membantu pekerjaan guru di rumah sehingga proses dan hasil belajar mereka tidak jauh berbeda dengan siswa lainnya di kelas. Selain itu kemampuan literasi siswa diskalkulia perlu ditingkatkan dan dibudayakan karena kaya literasi akan mempermudah pemahaman materi penyajian data.

\section{SIMPULAN DAN SARAN}

Dalam penelitian ini kesulitan belajar penyajian data siswa diskalkulia sekolah dasar dapat diatasi dengan menyusun desain didaktis dalam tiga tahap sehingga hasil belajar mereka tidak jauh berbeda dengan hasil belajar siswa normal. Hasil penelitian memperlihatkan bahwa desain didaktis dapat digunakan sebagai pilihan lain dalam strategi pembelajaran dan diterapkankan dalam kegiatan pembelajaran matematika di sekolah dasar karena dapat menurunkan rata-rata kesulitan belajar penyajian data siswa diskalkulia kelas 5 hingga 63,1\%.

Desain didaktis pada penyajian data siswa diskalkulia sekolah dasar yang dibuat ini diharapkan dapat memberikan arti terhadap pembelajaran penyajian data itu. Menjadikan pembelajaran yang bermakna untuk siswa diskalkulia dengan memakai metode dan media pembelajaran yang langsung mengajak siswa untuk berperan aktif dengan mula-mula dari kehidupan di keseharian dan memperhatikan kesulitan belajar siswa diskalkulia yang muncul kemudian. Untuk mengurangi kesulitan belajar yang muncul dan meningkatkan pemahaman siswa terkait materi penyajian data desain didaktis, penyajian data ini dapat digunakan oleh guru. Desain didaktis yang tercipta tidak 
tertutup kemungkinan masih bisa dikembangkan lagi lebih lanjut diiringi dengan budaya literasi bacatulis, yang sangat dibutuhkan dalam pembelajaran penyajian data di kelas 5 sekolah dasar. Oleh karena itu, perlu kolaborasi guru dan orangtua dalam pembelajaran matematika secara daring untuk mengurangi kesulitan belajar siswa diskalkulia sekolah dasar.

\section{PUSTAKA ACUAN}

Abdullah, D. "Desain Didaktis Materi Himpunan SMPIT Salman Cirebon Kelas VII." Pediamatika: Journal of Mathematical Science and Mathematics Education 1 (1), 2019: 91-102.

Delgado, M.A.C., Delgado, R.I.Z., Palma, R.P., Moya, M.E. "Dyscalculia and Pedagogiical Intervention." International Research Journal of Management, IT and Social Sciences 6 (5), 2019: 95-100.

Hannell, G. Dyscalculia: Action Plans for Successful Learning in Mathematics. Oxon, UK: Routledge, 2013.

Rohimah, Siti Maryam. "Analisis Learning Obtacles Pada Materi Persamaan dan Pertidaksamaan Linear Satu Variabel." JPPM 10 (1), 2017 : $1-9$.

Shim G.T.G., Shakawi, A.M.H.A \& Azizan. "Relationship Beetwen Students' Diagnostic Assessment and Achievement in a Pre-University Mathematics Course." Journal of Education and Learning 6 (4), 2017: 364-371.

Sugiyono. Metode Penelitian Pendidikan. Bandung: Alfabeta, 2013.

Suryadi, D. "Didactical Design Research (DDR) dalam Pengembangan Pembelajaran Matematika." Prosiding Seminar nasional Matematika dan Pendidikan Matematika. Bandung: STKIP Siliwangi, 2013. 3-12.

Warfield, Guy Brousseau dan Vaughan. Didactic Situations in Mathematics Education, Encyclopedia of Mathematics. Springer Dordrecht Heidelberg New York London: DOI, 2014.

Wiardani, N.K., Adiatmika, I., Paramita, D.P., \& Tirtayasa, K. "Adult Women Perception Towards Obesity and Its Intervention Strategies in the Community." International Journal of Health Science 2 (2), 2018: 46-60. 